\title{
Representations of industrial heritage in tourism marketing materials: Analysing androcentric discourse in textual and visual content
}

\section{Representações do património industrial em materiais de marketing turístico: Análise do discurso androcêntrico em conteúdos textuais e visuais}

\author{
Minéa Funk \\ Dalarna University, Sweden \\ Minea.Funk@salasilvergruva.se \\ Albina Pashkevich \\ Dalarna University, Sweden \\ alp@du.se
}

\begin{abstract}
This study uses a post-feminist lens to examine destination-marketing material connected to three sites in Bergslagen, an area located in the central part of Sweden famous for centuries of mining activity. This region continues to have ongoing mining operations, but has also worked at developing cultural and industrial heritage interpretations of its industrial past. A rich history of development based on mines, quarries and smelting huts has created a foundation for possible reinterpretations of history for tourism and became a ground for representation of metanarratives. In this study we analyse three sites located in the area of Bergslagen - Långban, Axmar Bruk (Axmar mill) and Engelsberg Bruk (Engelsberg mill). On-line textual and visual marketing materials used by these destinations allowed for the analysis of representations of the industrial heritage. Using post-feminist theory, we analysed representations of the industrial heritage in the marketing textual and visual materials of these chosen attractions. Our goal was to find the dominant representations as well as to explore what representations were missing from the stories told to the visitors. Our results show that both images and textual material continue to rely heavily on the representations of patriarchal system of Bergslagen and its industrial heritage, whereas the role of female and 'other' alternative narratives continue to be excluded. This study contributes to a deeper understanding of how marketing materials remain as facilitators in upholding male and female stereotypes connected to industrial heritage and the conclusions highlight the continued polarisation of gender through contemporary channels of communication.
\end{abstract}

Keywords: Bergslagen (Sweden); heritage; tourism marketing; post-feminist theory; representations.

\section{Resumo}

Este trabalho analisa, a partir da teoria pós-feminista, o material de marketing de destino em três lugares da região de Bergslagen (zona centro da Suécia), famosa pela sua atividade secular no campo da mineração. Essa região, na qual há ainda operações de mineração, tem trabalhado no sentido de desenvolver interpretações do seu património cultural e industrial. Trata-se de uma história de desenvolvimento das minas, pedreiras e cabanas de fundição, que criou uma base para possíveis reinterpretações da história do turismo e se tornou um terreno para a representação de

Dos Algarves: A Multidisciplinary e-Journal, 36-2020.

ISBN 2182-5580 @ ESGHT - University of the Algarve, Portugal.

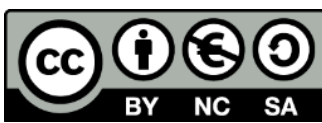

To cite this article: Funk, M. \& Pashkevich, A. (2020). Representations of industrial heritage in tourism materials: Analysing androcentric discourse in textual and visual content. Dos Algarves: A Multidisciplinary e-Journal, 36, 4158. DOI: 10.18089/DAMeJ.2020.36.3 
metanarrativas. Neste estudo, analisamos três locais na área de Bergslagen - Långban, Axmar Bruk (fábrica Axmar) e Engelsberg Bruk (fábrica Engelsberg). Os materiais de marketing textual e visual on-line utilizados por esses destinos permitiram a análise de representações do património industrial. Utilizando a teoria pós-feminista, analisamos representações do património industrial nos materiais textuais e visuais de marketing das atrações escolhidas. O nosso objetivo é encontrar as representações dominantes e explorar quais as representações que estavam ausentes nas histórias contadas aos visitantes. Os resultados mostram que tanto as imagens quanto o material textual continuam dependendo fortemente das representações do sistema patriarcal de Bergslagen e da sua herança industrial, enquanto o papel das narrativas femininas e de 'outras' alternativas continua excluído. Este estudo contribui para uma compreensão mais profunda de como os materiais de marketing permanecem como facilitadores na defesa dos estereótipos masculinos e femininos conectados ao património industrial e as conclusões destacam a contínua polarização de género através dos canais de comunicação contemporâneos.

Palavras-chave: Bergslagen (Suécia); património; marketing turístico; teoria pós-feminista; representações.

\section{Introduction}

A destination's attractiveness is usually defined by its geography, nature or heritage, and therefore destinations will promote themselves with reference to the qualities attached to the place (Ren \& Blichfeldt, 2011). These qualities then become representations of a destination (Daugstad, 2008; Sims, 2009). Keskitalo and Schilar (2017) and Pashkevich (2017) argue that this process may lead to simplifying the representations in order to attract visitors, and in doing so marginalise some narratives. This in turn prompts the question of which image(s) of the heritage is/are being projected through marketing efforts. Marketing enhances the image of the destination through texts and pictures; therefore language becomes a tool which creates perception and representations of the destination being marketed. Waterton and Watson (2014: 54) claim marketing has become "one of the most powerful narratives in the semiotic landscape of heritage attractions", and as a tourist's first knowledge of a destination are the representations it is imperative to understand the importance of the language used in the textual and visual content of marketing (Kolcun, Kot \& Grabara, 2014).

The marketing of a destination can play a part in the marginalisation of certain representations, which would suggest that some interpretations are lost or suppressed in the process of creating an attraction (Pashkevich, 2017). In turn, such a process suggests a power struggle between different narratives; where some are considered as more important representations and thus used in the marketing, while others may be suppressed (Ren \& Blichfeldt, 2011). Such power relations facilitate social construction and create human perception of what is real. In accordance to post-structural thought, reality is considered as being socially constructed, which in turn implies that it is necessary to understand the systems and structures that create reality in order to understand what exists within it (Hall, 1997; Coleman, 2014). Thus, what we understand as being the representations of a heritage in turn also affects our understanding of reality (Coleman, 2014). The representations and their narratives are therefore used in contextualising and producing a touristic place (or destination). 
The mining industry has played a crucial part in the development of Sweden as a nation since the $16^{\text {th }}$ century (Jakobsson, 2009). Most of the metals came from the region in the middle of the country known as Bergslagen. It is interesting to note that Bergslagen has never been an administrative region nor had an actual boundary surrounding it (Calissendorff, 1988; Ekman, 1996). Therefore, today there are different perceptions on what constitutes this area geographically and culturally. Different stakeholders on regional and local levels have contributed to the creation of an array of images which became problematic when applied to Bergslagen as one touristic destination (Jakobsson, 2009). The industrial heritage, comprising a long history of industrial exploration and mining activities in Bergslagen, constitute a valuable resource for socio-economic development in the form of tourism.

This paper aims to analyse what representations of Bergslagen's industrial heritage are being projected through marketing material. Our objective is to apply post-feminist theory to detect androcentric discourses in the representations of Bergslagen's industrial heritage. This study seeks answers to two main questions: 1) What representations can be found in the marketing materials of the industrial heritage of the selected tourist destinations in Bergslagen? 2) What are the dominating representations of industrial heritage? 3) Are any representations, which could have been found, missing from the material?

\section{Theoretical considerations}

Feminist theories aim to understand gender relations and how gender is produced within social relations. They can help to explain how normative gender assumptions are being reproduced and create a framework to understand gender differences, inequality and oppression (Aitchinson, 2005; Cook \& Fonow, 1986; Ollivier \& Tremblay, 2000). Postfeminism includes both feminist theories as well as other anti-foundational movements such as postmodernism, post-colonialism and post-structuralism. Post-feminist research understands a reality as a construct and aims to recognise the structures and systems which uphold what we understand as a reality (Brooks, 1997). Gender is considered to be constructed and produced continuously, for example through dichotomies such as man/woman and different values associated with different genders such as femininity and masculinity (Bergdóttir, 2016). These values position man and woman as opposites of each other and it should also be assumed that post-feminist research aims at understanding more than just the relation between man/woman but also of diversity, hierarchy and what is other (Lykke, 2010; Robert, 2014).

Post-feminist theory can help to explore the social roles of men and women throughout the history of industrial mining production and how its heritage is being represented today. Moreover, as gender is an intangible social construct it is the manifestations of humanity which can be analysed in order to understand the underlying systems of reality (Bergdóttir, 2016). Many such manifestations can be found in museums and exhibitions, where culture and heritage are being preserved. Robert (2014) explains how these types of exhibitions tend to be heteronormative collections and narratives which marginalise alternative narratives and representations. The hegemony of white middle-class, heterosexual men and women is 
evident and suggests power structures within the dichotomies as well (Collins, 2012). Often, man and masculinity play a pivotal role, thus creating stereotypical androcentric representations and discourse of most cultural heritage (Coleman, 2014).

Androcentrism is the practice of placing man and masculinity at the centre of the worldview and as the norm of humanity. Thus, androcentric discourse upholds the patriarchy and creates gender polarisation, it positions man and woman as profoundly different from one another which in turn reproduces androcentric discourse and maintains the hierarchal social order (Bailey \& LaFrance, 2017; Bem, 1993). Androcentric discourse is highly critiqued by post-feminist theory in problematising the reciprocal relationships between genders (Martin \& Papadelos, 2017). This type of androcentric discourse becomes embedded in traditions, mannerisms and language, which perpetuates these constructs (Bailey \& LaFrance, 2017).

Industrial heritage has become a valuable resource in tourism development as well as becoming one of the fastest growing speciality markets in recent decades (Bordeau \& GavariBarbas, 2016; Jakobsson, 2009; Pashkevich, 2017). In return, tourism is considered a tool in the preservation of heritage and as an asset in the process for continued regional development and rejuvenation of post-industrial areas (Xie, 2015a). The increase of industrial heritage tourism can be attributed to the continued deindustrialisation of society (Jakobsson, 2009), where the desire to revisit places of modern history awakens a sense of nostalgia among visitors. Halewood and Hannam (2001) refer to industrial heritage sites as the "landscapes of nostalgia". Industrial sites such as mines and quarries, mills or breweries today facilitate their visitors by offering a range of activities, foods and events (Ćopić et al., 2014; Lew, 2017). Several stakeholders play pivotal roles in the development and preservation of such destinations. Hultman and Hall (2011) argue that these type of destinations (attractions) are being constructed by the practices and social relations within. It also means that an industrial heritage destination is reflexive of the context in which it exists and therefore dependent on and changing as different stakeholders participate in its construction.

Heritage, or cultural heritage, is complex and includes many facets of cultural representation. Industrial heritage includes tangible remains of industry - the buildings, equipment as well as the surrounding landscapes, the settlements, products as well as the intangible elements represented by knowledge of the technological processes and historical documents (Xie, 2006). Cultural heritage tourism is connected to the practice of touristic activities in these man-made landscapes, where the heritage has been reproduced for touristic value (Edwards \& Llurdes, 1996; Pashkevich, 2017). As these post-industrial landscapes are being perpetually reproduced or even reimagined through tourism, poststructural thought will suggest this is a way to also regenerate meaning and create a new sense of the environment and world surrounding us (Xie, 2015b).

By understanding which power relations have existed in Bergslagen during the centuries of production we can begin to understand and analyse which narratives are, allegedly, being marginalised currently through the marketing of the destinations. The industrial heritage of Bergslagen can be presumed to be of androcentric nature (Abrahamsson et al., 2014; Pritchard \& Morgan, 2000), where the representations of man and masculinity have played a 
pivotal role in the culture (Bergdóttir, 2016; Jakobsson, 2009). Ohlander and Strömberg (1996) and Blomberg (2006) prove that during the pre-industrial period many women worked in the iron ore mines in Bergslagen. Between 1700-1850 women worked both above and below ground with many different tasks. In some mines, the female workers accounted for half of the total labour force. Moreover, during this period the whole household often worked in the mining industry, while combining life with farming or other activities (Abrahamsson et al., 2014). From the 1850s, women almost disappeared from mining as the opinion against women in the mining work force in general was starting to grow during the industrialisation period. Women in mining were criticised for their lack of suitability for heavy manual labour underground alongside their male co-workers, which according to some voices, could render women incompetent as wives and mothers (Blomberg, 1995). Additionally, in 1900, Sweden passed a new law forbidding women from working underground (it remained law until 1978). According to Abrahamsson et al. (2014) and Blomberg (1995) it should be clear that mining once was fairly common and normal work for women in Sweden. Today, the mining industry is a heavily male-dominated sector, with 90$95 \%$ of the workers being men. Andersson, Abrahamsson, Fältholm and Lindberg (2013) claim that the mining workplaces have been, and still are, male dominated in the obvious way, but also in a discursive and cultural sense. The male ideals have long dominated structures, practices and procedures (Andersson, 2012). As in many other male-dominated industrial workplaces, Tallichet (2000) has found that the work culture is often based on masculinity, the male homo-socialisation and exclusion of "others" as less suitable to perform hard work.

By using a post-feminist understanding we can analyse whether power relations of gender and the marginalisation of female narratives continue today and if power structures, connected to the patriarchy, still prevail in the representations of the heritage today. The language used in the communication of an image or brand of the destination is a powerful tool in perpetuating these power structures and for the construction of reality (Whorf, 1956; Luchini, 2010). We can use this understanding to explain if and how heteronormative assumptions of gender are still being used in (re-)producing the representations of the industrial heritage today (Bergdóttir, 2016).

The texts and visual images in promotional material are used to project the representations of the heritage to the world. This means that by analysing this type of content we can attempt to understand which underlying structures exist (Bryman, 2002). As content analysis examines these structures, within the context of Bergslagen and its androcentric discourse we should be able to detect if these power relations exist in the process of choosing what was deemed as important enough to represent the heritage in the first place - which, in fact, has derived from said context.

\section{Study area and methods}

\subsection{Study area}

The area of Bergslagen has been a significant region for mining industries and the economic development of Sweden throughout its history for many centuries (Ekman, 1995; Jakobsson, 
2009). This study utilises the area of Bergslagen as an example of recent processes of redevelopment of old mining sites for touristic purposes. This type of development has been ongoing for several decades, introducing nature, adventure and industrial heritage tourism as a way of re-vitalising these areas (Jakobsson, 2009; Pashkevich, 2017). Decades of investment on national and regional levels have made this area into a leading destination connected to the use of industrial heritage by developing infrastructure, cultural projects and funding local start-up businesses (Pashkevich, 2017). Moreover, in order to maximise the growth and development of tourism in the area of Bergslagen, a ten-year (2007-2018) investment project was created jointly by the Swedish National Heritage Board (Riksantikvarieämbetet) and five regional County Administration Boards. The project was funded by the European Development Fund (ERDF) and thirteen different destinations within the five counties in Bergslagen (Intresseföreningen Bergslaget, n.d.). It was called Bergslagssatsningen and became the largest regional collaborative funding project in the region. For the purpose of this study, the tourist destinations which partook in this project were considered for further analysis.

The material analysed for this study was collected from the websites of three industrial heritage destinations within the area of Bergslagen. The first one is a mining area of Långban, located in the region of Värmland, which is one of the best-preserved industrial heritage landscapes in Sweden (Länsstyrelsen Värmland, 2018). The second, Engelsberg Ironworks, in the region of Västmanland, is considered one of the world's prime industrial heritage sites of its kind and a part of the UNESCO's World Heritage List since 1993 (Länsstyrelsen Västmanland, 2018; UNESCO, 2018). The third destination is Axmar Mill, located in the province of Gästrikland, consisting of both mining and coastal industrial heritages (Länsstyrelsen Gävleborg, 2018). All three destinations are re-interpreted iron works - for iron ore mining and production of iron. Furthermore, all three destinations focus on tourism both "above ground" and within the underground mines, showing the heritage buildings, domestic/living quarters, i.e. where the workers lived, infrastructure, equipment as well as natural resources and landscapes. Another common feature for these chosen destinations is that they offer guided tours and display the manifestations of the heritage in museums and exhibitions. Moreover, as there were five different Swedish counties participating in the project Bergslagssatsningen, it was also important to have a wide geographical representation of these counties. The destinations chosen for this study were selected through purposive sampling - chosen through pre-set criteria based on the characteristics of the population and the objectives of the study (Berg \& Lune, 2004). These criteria aimed to have a homogenous group with as many similar characteristics as possible, which also meant applying homogenous sampling (Patton, 2005; Veal, 2011). These two sampling methods are known to be judgmental, selective and subjective, and therefore prone to research bias. In order to minimise bias the sampling has been based on the use of a solid theoretical framework (Bryman, 2002; Patton, 2005).

\subsection{Method}

The content analysis was used in order to identify which semantics could be found in the data 
collected - the texts and pictures used in marketing on the websites of the three chosen destinations. The method was used to systematically summarise and analyse all written and visual content as a way of discovering underlying themes (Bryman, 2002). Content analysis has usually been used to analyse published texts such as documents and speeches, however the understanding of what can be considered as texts has widened to include a variety of cultural expressions such as pictures, advertising, websites or maps (Veal, 2011). Content analysis can be said to be descriptive, as it is based on recognising and counting attributes in data (Jenkins, 2003). It aims to examine the manifested as well as latent content of textual data. The former refers to the visible and apparent components known as denotations; the latter refers to the meaning behind the texts, the connotations (Insch, Moore \& Murphy, 1997). The goal of content analysis is to produce qualitative descriptions or explanations of the data collected; however, the process also suggests it as quantitative and thus replicable due to its statistical nature. The analysis demands subjective interpretations based on theory applied in order to detect the underlying meaning or structure to detect possible connotations (Bryman, 2002; Holsti, 1969).

\subsection{Data collection and analysis}

The data from the official websites ${ }^{1}$ of the chosen destinations was collected during the period of 7 to 13 May 2018. The content used in the study were promotional texts and pictures. As the information presented by the websites was in Swedish, the textual content has been translated by the researchers for the purpose of presenting the findings. The texts will be presented through quotes from the websites, such as: "The brothers John and Nils Ericsson were both prominent people, who both put their stamp in the world and in Sweden" (Värmlands Museum, 2018). However, examples of pictures are not presented in this study due to the copyright restrictions in Sweden. The entire data content of the websites generated a total of 54 pages of text and 288 images. The total amount of the content collected from each website was quite different in size, as the visual and textual content of each website varied in size. However, as the aim of the study was not to quantify the data collected, we found no issue with the amount of available data.

The analysis of the data was conducted using the general techniques of Conventional Content Analysis. By not applying pre-determined codes or categories but instead immersing in the data allowed for categories or key codes to appear from the data itself (Hsieh \& Shannon, 2009; Kondracki \& Wellman, 2002). Miles and Huberman (1994) explain that the data must be read thoroughly and word by word in order to derive appropriate codes. These codes will later lead to categories or labels being formed as codes are linked together. The data is this study was analysed in an interpretive matter with the intention to identify distinct categories. In total 14 categories were found, including Nature, Heritage building, Historical portraits, Entertainment. Some of the text and pictures were categorised into more than one of the categories depending on the predominant motif or meaning detected. Later these

${ }^{1}$ https://varmlandsmuseum.se/langban/; https://www.axmarbruk.se; http://www.engelsberg.se. 
categories were arranged into four main themes: Nature, Manifestations of the heritage, Historical Importance and Touristic Interpretations.

As the objective was also to detect whether an androcentric discourse is apparent in the representations of the industrial heritage the content analysis also included the people being represented in the data. Rooted in the literature of post-feminist theory and androcentrism the study aimed to detect if potential connotations existed within the data. The denotations of the words and motifs in the pictures were therefore categorised into gender (man or woman) as well as age (adult or child). The texts and pictures were then also cross-tabulated into the previously mentioned themes. However, people were only present in two of the four themes - Historical Importance and Touristic Interpretations, leaving the other two themes without people, which in turn suggested another category - "no people".

\section{Results}

In total, 1073 representations were found and categorised into 14 different categories. Table 1 presents the recurrence of all 14 categories. The three different destinations presented different recurrences of representations, where Nature was the most frequent category on the Långban and Axmar mill websites while Working Environment was more frequent for the Engelsberg Ironworks.

Table 1. Number of occurrences by category $(\mathrm{N}=1073)$, statistical order

\begin{tabular}{|c|c|c|c|c|}
\hline Categories & Pictures $(\mathrm{N}=395)$ & Text $(\mathrm{N}=678)$ & Total (N) & Total (\%) \\
\hline Nature & 113 & 66 & 179 & $17 \%$ \\
\hline Heritage buildings & 112 & 24 & 136 & $13 \%$ \\
\hline The name & 1 & 106 & 107 & $10 \%$ \\
\hline Events & 80 & 20 & 100 & $9 \%$ \\
\hline Historical portraits & 4 & 93 & 97 & $9 \%$ \\
\hline Dates & 0 & 89 & 89 & $8 \%$ \\
\hline Working & 7 & 68 & 75 & $7 \%$ \\
\hline Anecdotes & 0 & 67 & 67 & $6 \%$ \\
\hline Activities & 11 & 44 & 55 & $5 \%$ \\
\hline Tourists & 43 & 11 & 54 & $5 \%$ \\
\hline Mineral & 3 & 47 & 50 & $5 \%$ \\
\hline Food \& Board & 14 & 33 & 47 & $4 \%$ \\
\hline Exhibitions & 7 & 10 & 17 & $2 \%$ \\
\hline \multirow[t]{2}{*}{ Bergslagen } & 0 & 0 & 0 & $0 \%$ \\
\hline & 395 & 678 & 1073 & $100 \%$ \\
\hline
\end{tabular}

The categories were organised into four dominant themes: Nature, Manifestations of the heritage, Historical importance and Touristic interpretations, which can be found in Table 2 . 
Table 2. Frequency of categories by thematic groups $(\mathrm{N}=1073)$, in order of appearance in this article

\begin{tabular}{|l|c|c|c|c|}
\hline Thematic groups & Pictures (N = 395) & Text (N = 678) & Total (N) & Total (\%) \\
\hline Nature & & & & \\
\hline Nature & 113 & 66 & 179 & $17 \%$ \\
\hline Mineral & 3 & 47 & 50 & $5 \%$ \\
\hline Total & 16 & 113 & 229 & $\mathbf{2 1 \%}$ \\
\hline
\end{tabular}

\begin{tabular}{|l|c|c|c|c|}
\hline Manifestations of heritage & & & & \\
\hline Heritage buildings & 112 & 24 & 136 & $13 \%$ \\
\hline Workings & 7 & 68 & 75 & $7 \%$ \\
\hline Total & $\mathbf{1 1 9}$ & $\mathbf{9 2}$ & $\mathbf{2 1 1}$ & $\mathbf{2 0} \%$ \\
\hline
\end{tabular}

\begin{tabular}{|l|c|c|c|c|}
\hline Historical importance & & & & \\
\hline The name & 1 & 106 & 107 & $10 \%$ \\
\hline Historical portraits & 4 & 93 & 97 & $9 \%$ \\
\hline Dates & 0 & 89 & 89 & $8 \%$ \\
\hline Anecdotes & 0 & 67 & 67 & $6 \%$ \\
\hline Bergslagen & 0 & 0 & 0 & $0 \%$ \\
\hline Total & 5 & 355 & 360 & $34 \%$ \\
\hline
\end{tabular}

\begin{tabular}{|l|c|c|c|c|}
\hline Touristic interpretations & & & & \\
\hline Events & 80 & 20 & 100 & $9 \%$ \\
\hline Activities & 11 & 44 & 55 & $5 \%$ \\
\hline Tourists & 43 & 11 & 54 & $5 \%$ \\
\hline Food \& Board & 14 & 33 & 47 & $4 \%$ \\
\hline Exhibitions & 7 & 10 & 17 & $2 \%$ \\
\hline Total & $\mathbf{1 5 5}$ & $\mathbf{1 1 8}$ & $\mathbf{2 7 3}$ & $\mathbf{2 5 \%}$ \\
\hline
\end{tabular}

The most frequent theme was Historical Importance, accounting for $34 \%$ of the sample.

\subsection{Theme: Nature}

Nature is a prominent theme in the marketing material used by all three destinations. Nature is also almost as frequent in pictures as in texts. This theme makes up $21 \%$ of the sample. Nature or natural elements detected in the material included mountains, forests, lakes, gardens (the cultivated landscape), as well as natural resources such as ore and minerals.

The pictures of Nature were often void of people, except for the representations of activities being exercised in nature by people such as a guided tour. Many of the pictures of nature also included buildings or industrial infrastructure. While in the textual content nature was manifested through descriptions of the scenery. "[...] still has much of the original beauty with the great deciduous trees, ponds and gazebo." stated on Axmar Mill's website (Axmar Bruk, 2018). The scenery and the natural resources were also often mentioned 
together, "Engelsberg had the access to iron ore, watercourses, systems of lakes and vast forests and was therefore an excellent site for an iron works" (Fagersta Kommun, 2018). The representations of natural resources were however fewer than of the nature/scenery. In pictures the natural resources were always present in the context of an exhibition and when used in a text were commonly linked to the history of the heritage and its importance in the history of the heritage site. For example, Långban's website: “[...] one of the most mineral rich places in the world. 1.8 billion years ago these minerals were formed, and the iron ore begun being mined in the 16th century" (Värmlands Museum, 2018).

\subsection{Theme: Manifestation of the heritage}

The least prominent theme, $20 \%$ of the sample, was the manifestations of the cultural heritage and thus the material or tangible culture. This theme included heritage buildings, infrastructure, interior, working environments, tools, equipment and clothes. These are the tangible expressions of the intangible culture. Most representations were visual and the pictures frequently depicted buildings in the landscape without people being present. The types of buildings in the analysed material varied from castles to water wheels, or buildings used for production. In the textual content buildings were mentioned, for example in the context of preservation: "The only ironworks in Sweden that preserves buildings as well as the technical equipment" (Fagersta Kommun, 2018).

The working environment and culture connected to the industrial buildings were represented through tools, clothing and what was being produced. These representations were only half as many in recurrence as the heritage buildings. Just a few of the pictures had representations (7 out of 75) of the working environment and culture, these were of clothing or working equipment. However, in the textual content these types of representations were many and referred to the production in historical terms. Words often used were mining or production; "Already in the $16^{\text {th }}$ century iron ore was being mined in order to produce iron at Långban” (Värmlands Museum, 2018).

\subsection{Theme: Historical importance}

The largest theme was Historical importance accounting for $34 \%$ of the sample which included occurrences of important historical dates, anecdotes, portraits of people connected to the heritage sites as well as the mentioning of the name of the destination or site. The last example, the name, has the most common recurrence overall particularly in texts. A total of 360 representations were found; however only five were found in the visual content, leaving this theme the smallest among the visual representations.

The pictures were almost exclusively (4) portraits or groups of people. All representations of people were of men, either in the portrait of an esteemed man or groups of male workers. There were no representations of women or children. In the textual content the mentioning of named or historical/important people was comparable to the portraits. Male names were in the majority, where their title and/or contribution often accompanied the name. There were no children mentioned throughout the analysed material, except for sometimes one could find mentioning of them as "the daughter of" or "the brother of". 
However, they were not categorised as children in the current analysis since it was not clear what age they were. "The daughters" were categorised as mentioning women, and "the brothers" as men. "The brothers John and Nils Ericsson were both prominent people, who both put their stamp in the world and in Sweden", stated at Långban's website (Värmlands Museum, 2018).

Throughout all textual content, women were only represented in this theme. Representations were found only 18 times, in comparison to men being mentioned 75 times. It was also common that the same woman was mentioned several times, thus portraying her as particularly important, or perhaps, distinguished as in the case of Brita Behm of Axmar mill: "Brita Behm, generally known as Iron Brita, became 85 years old and, at the time of her death in 1755, had been the ruler of the iron works for 58 years" (Axmar Bruk, 2018).

Apart from the portraits, there was only one other picture representing the historical importance of the place, the mentioning of the name on a sign. All other representations of the historical importance of the site itself was interpreted in the textual content. "Then a string of incidents happened at Långban that changed the world forever." (Värmlands Museum, 2018) and "Engelsberg Ironworks is the best preserved ironworks in Sweden." (Fagersta Kommun, 2018). It is interesting to note that there is a noticeable absence of the mentioning of Bergslagen. The name of the region is absent from all textual and visual content on all three studied websites.

\subsection{Theme: Touristic interpretations}

The touristic interpretations comprised $25 \%$ of the sample and included representations of reinterpretations of the heritage for its touristic value. These were presented by depictions of guided tours or other activities, exhibitions, food samples, as well as facilities for lodging, entertainment and events at the destination. Representations of entertainment were the largest and most common in the visual representations. These depicted events were of traditional character connected to the traditional Swedish events such as Christmas markets or Walpurgis night.

Exhibitions were represented in pictures from different types of exhibition settings or via posters for them. In the textual content both events and exhibitions were scarcely mentioned, however some could be found: "In this exhibition you can follow John Ericson's work on constructing the world's first-ever-armoured aircraft gun", from an exhibition at Långban mining area (Värmlands Museum, 2018). Pictures of leisure activities such as hotels or restaurants became representations for food or lodging, though there were no depictions of actual food or products. Instead, there were pictures of the exteriors, some interiors or of plates. In the texts the representations described the types of facilities available at the destination such as: “In Anna Karolina's kitchen in John Ericssongården, you will find savoury home cooking and homemade cakes”, from Långban's website (Värmlands Museum, 2018). Some touristic activities, such as guided tours, were represented in pictures depicting groups of people. In the pictures, 43 representations of people were found. They were often tourists, mostly as part of a group and thus not categorised into different genders. 


\subsection{Representations of people and gender}

Visual material depicting people was divided into categories consisting of two, with gender specified in sub-categories. These themes were Historical importance, where people were depicted in historical portraits, and Touristic interpretations, where people were depicted as visitors. Table 3 provides an overview of the representations of people and gender by category.

Table 3. Representations of people and gender in categories and sub-categories $(\mathrm{N}=151)$

\begin{tabular}{|l|c|c|c|c|}
\cline { 2 - 5 } \multicolumn{1}{c|}{} & Pictures (N = 4) & Texts (N = 93) & Total (N) & Total (\%) \\
\hline Historical Portraits & & & & \\
\hline Men & 4 & 75 & 79 & $81 \%$ \\
\hline Women & 0 & 18 & 18 & $19 \%$ \\
\hline Children & 0 & 0 & 0 & $0 \%$ \\
\hline
\end{tabular}

\begin{tabular}{|l|c|c|c|c|}
\cline { 2 - 5 } \multicolumn{1}{c|}{} & Pictures (N = 43) & Texts (N = 11) & Total (N) & Total (\%) \\
\hline Tourists & & & & \\
\hline Groups & 24 & 11 & 35 & $65 \%$ \\
\hline Men & 8 & 0 & 8 & $15 \%$ \\
\hline Women & 8 & 0 & 8 & $15 \%$ \\
\hline Children & 3 & 0 & 3 & $6 \%$ \\
\hline
\end{tabular}

In the theme Touristic interpretations people were more frequently represented in the visual content. However, people in this category made up only $4 \%$ of the representations of the entire data collected. In the pictures, people were tourists or staff/guides and were often seen as part of a group. These people were present in different types of settings - on guided tours in nature or in an exhibition. The pictures of groups were eclectic in terms of gender and age, and were therefore not categorised into man, woman or child. Noticeably, children were only present in pictures with a woman or with a woman and man, presumably representing a family. In the textual content people were only mentioned as gender neutral, as a group of tourists.

In the Historical importance theme people were represented just four times in the visual content. They were either historical portraits of a man or a part of a group of workers standing together wearing uniforms and holding other equipment, which obviously represented the working environment of the men. As previously stated, women and children were not depicted by any of these pictures. In the textual content both males (75 recurrences) and females (18 recurrences) were mentioned, usually through the mentioning of their names. Males however were often referred to by their title, such as Captain, Patron, King or Professor. While females often were referred to in their relation to a man, such as "the widow of" or "the daughter of". For example, "Albrecht Behm's daughter Brita, married to a professor, Johan Swede, became a widow in 1697 and took over the responsibility for the operation of Axmar Mill" (Axmar Bruk, 2018). Another example: "Their sister Anna- 
Karolina had to stand back to the success of her brothers, but was considered to be the most bright of the siblings" (Värmlands Museum, 2018). Furthermore, the same female's name is also given to a restaurant: "In Anna-Karolinas kitchen in John Ericssongården [...]" (Värmlands Museum, 2018). It is of course also important to notice that only the kitchen/restaurant is named after her, a woman, while the whole manor, in which the restaurant is situated, is named after her famous brother John Ericsson.

Adding the two categories where people were present, males represented the majority of the representations with a total of $58 \%$, while females accounted for only $17 \%$. Figure 1 illustrates the recurrence of people by gender.

Figure 1. Recurrence of people by gender

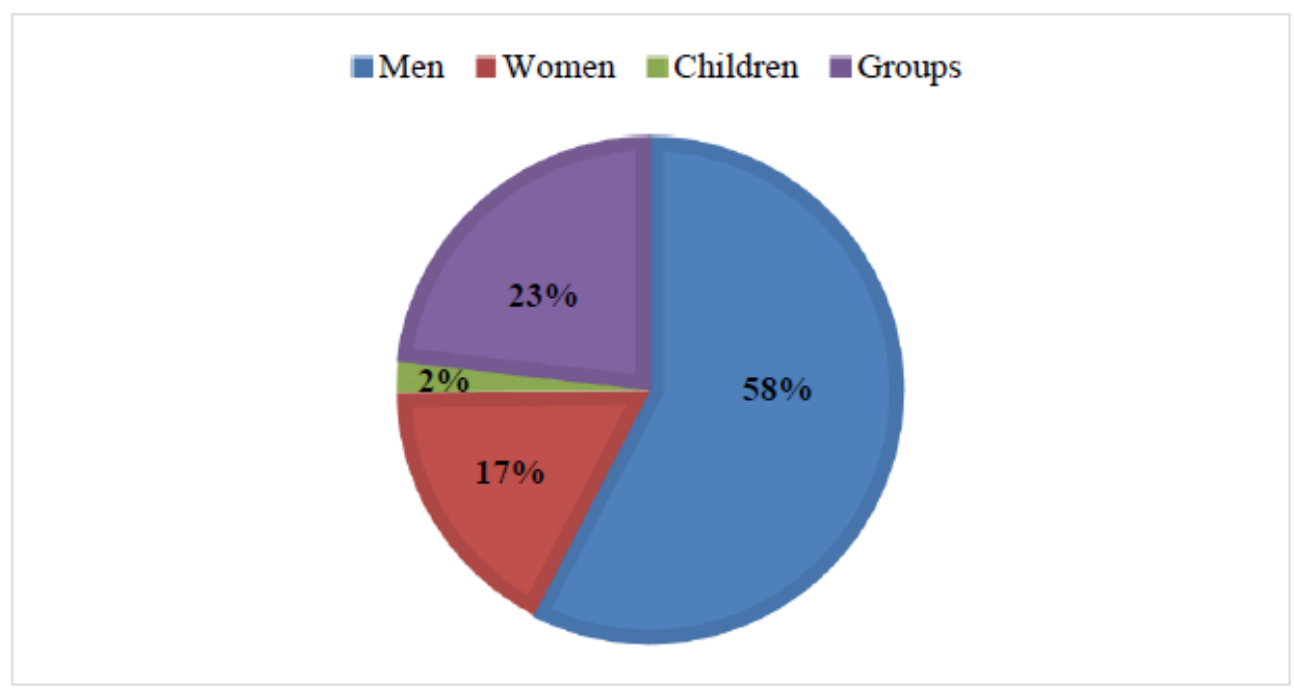

\section{Concluding remarks}

This study analysed the textual and visual representations found in the online material available from the three chosen destinations situated in the area of Bergslagen.

Destinations usually promote themselves in reference to the qualities of their cultural heritage (Ren \& Blichfeld, 2011), which therefore implies that the destinations are being marketed as genuine and authentic places to visit. The material used in marketing is thereby the "genuine" representation of the heritage itself. However, as the heritage is both the resource as well as the product being sold several matters need to be considered (Archer, Cooper \& Ruhanen, 2012). On the one hand it is necessary to simplify heritage for both marketing and later consumption, which has resulted in the production of rather stereotypical representations of heritage sites due to the marginalisation and polarisation of narratives (Keskitalo \& Schilar, 2017; Pashkevich, 2017; Ren \& Blichfeldt, 2011). The representations have thus become a construct of the context in which it exists. In our study, it has become evident that male narratives have been enhanced and dominated both within textual and visual content, while "other", such as the female, has been supressed. As Bergdóttir (2016) and Coleman (2014) explained it is common that female narratives become marginalised in this power struggle, as man and masculinity are considered the norm when 
describing industrial workplaces and technological development androcentric discourse (Abrahamsson et al., 2014; Pritchard \& Morgan, 2000).

Overall, there are four themes which were found to be dominating both visual and textual marketing content. The first theme was Nature with visual and textual content depicting nature and landscapes of each destination. The nature has been historically cultivated for industrial purposes and to generate revenue. Even though there were no direct representations of people in studied images and textual material, people were still present as exploiters, architects and producers of the cultivated landscapes and nature. Nature is therefore a prominent part of the industrial heritage and people can thus be detected in the content even though they were not "physically present". The actual manifestations of people were evident in the representations of infrastructure, products and tools. It also became evident that the heritage portrayed in the marketing material is the heritage of men. In this context, men can be considered as the producers of manifestations and thus also the heritage. The mining industry has historically been a workplace for men (Ekman, 1996), thus suggesting that it should be the male heritage which is preserved and presented. Postfeminist thought problematises the use of androcentric discourse where man is considered superior to woman (Bailey \& LaFrance, 2017). Not only are women being marginalised, but also children or different social classes excluded from the representations of mining heritage at chosen locations. They are therefore considered as the "other" to the norm or standard and thus less human (Bergdóttir, 2016; Robert, 2014).

This is also apparent in the theme Historical importance, with representations of the heritage being depicted by males of a higher social class, the Patrons or Professors often on their own in portraits, while the workers always pictured as part of a group wearing their working gear. Few females were represented in this theme (texts), but the ones who were mentioned were apparently of a higher social class, often mentioned in connection to their husbands, brothers or father figures. Once again, it is not only females who are neglected in the narratives, but children, immigrants, and people of other social classes were also missing from the representations.

The theme for Touristic interpretations represented by heteronormative standards and binary gender roles in the depictions of visitors to the sites. Women and children are pictured together, suggesting a link between them as mother and child, or a child with a man and a woman, representing a family. However, tourists represented in group settings were far more common, which suggests touristic activities are being represented as gender neutral and inclusive. However, children were still missing in these representations implying that industrial heritage tourism is aimed at attracting adults.

This study also found that females' roles in the history of industrial development of the analysed sites were reduced to the roles played by man. Thus, females were often portrayed as a widow or a sister, which suggests their place in the hierarchal social order in the portrayal of industrial heritage. Still, most of the females found in the data had a high social standing. Androcentric discourse implies that different genders must fulfil different roles in a society for social order to exist (Lakoff \& Bucholtz, 2004). The illustration of the existing social order became evident in the textual content describing a restaurant being named after a female 
and a manor after a male, implying the woman's role as the homemaker and man holding a position of a breadwinner.

Thus, marketing content is continuing to stereotype females as different from males, which is supporting the previously accepted patriarchal social system. Like many other similar heritage sites, Bergslagen is steeped in nostalgia (Pashkevich, 2017). These destinations represent centuries of hard male-dominated work, reinforced by images of man taming nature and human ingenuity. It is through the immaterial and material representations via landscapes and architecture which continue to awaken these sensations in visitors. The uncritical reproduction of previously inherited representations in modern tourism marketing creates negative connotations and continues to reject the establishment of the preconditions for a wider participation in the touristic consumption of cultural industrial heritage. Exhibitions of cultural heritage tend to produce heteronormative collections of narratives (Robert, 2014). The language and pictures used in the promotional materials therefore continue to sustain their role as powerful tools in perpetuating gender stereotypes (Bailey \& LaFrance, 2017; Bem, 1993; Berger \& Luckmann, 1967).

Repetitive use of heritage dominated by males and male manifestations through the cultural landscapes of mining industry with its tangible heritage, as well as the upholding of the importance of certain men for the history of industrial development, supports the marginalisation of other narratives. Thus, the marketing materials are perpetuating this historical androcentric worldview, which still exists in the industrial sites of Bergslagen. Such semantics may not always be evident, but clearly found as connotations reproducing stereotypical traditional gender roles connected to the patriarchal hierarchal legacy of mining. Decoding the industrial heritage representations and illuminating possible problems in promotional materials is a necessity for the creation of better and more nuanced understanding and thus acknowledgement of the real and genuine industrial heritage. As a desire to experience the "genuine" and "authentic" heritage seems to be important for modern visitors, it is crucial for destinations to be able to deliver it on that premise.

\section{References}

Abrahamsson, L., Segerstedt, E., Nygren, M., Johansson, J., Johansson, B., Edman, I., \& Åkerlund, A. (2014). Gender, diversity and work conditions in mining. Sweden: Luleå University of Technology.

Andersson, E. (2012). Malmens manliga mysterium: En interaktiv studie om kön och tradition i modernt gruvarbete (unpublished doctoral thesis). Luleå University of Technology, Sweden.

Andersson, E., Abrahamsson, L., Fältholm, Y. \& Lindberg, M. (2013). Breaking ore and gender patterns. A strategic and sustainable R\&l-agenda for the Swedish mining industry. Luleå Tekniska Universitet, Institutionen för ekonomi, teknik och samhälle

Aitchison, C. C. (2005). Feminist and gender perspectives in tourism studies. Tourist Studies, 5(3), 207244. doi: $10.1177 / 1468797605070330$

Archer, B., Cooper, C. \& Ruhanen, L. (2012). The positive and negative impacts of tourism. In W.F. Theobald (Ed.), Global Tourism (pp. 79-102). New York: Routledge.

Axmar Bruk (2018). Bruket vid Axmar strömmar. Retrieved from https://www.axmarbruk.se/historia 
Bailey, A.-H. \& LaFrance, M. (2017). Who counts as human? Antecedents to androcentric behavior. Sex Roles, 76, 682-693. doi: 10.1007/s11199-016-0648-4

Bem, S. L. (1993). The lenses of gender: Transforming the debate on sexual inequality. New Haven, CT: Yale University.

Berg, B. L. \& Lune, H. (2004). Qualitative research methods for the social sciences (Vol. 5). Boston: Pearson.

Bergdóttir, A. (2016). Museums and feminist matters: Considerations of a feminist museology. NORA Nordic Journal of Feminist and Gender Research 24(2), 126-139. doi: 10.1080/08038740.2016.1182945

Berger, P. \& Luckmann, T. (1967). The social construction of reality: A treatise in the sociology of knowledge. Garden City, N.Y.: Anchor Books.

Blomberg, E. (1995). Män i mörker: arbetsgivare, reformister och syndikalister: Politik och identitet i svensk gruvindustri 1910-1940 (unpublished doctoral thesis). Stockholm University, Swedish.

Blomberg, E (2006). Gender in ironmining communities in Sweden 1900- 1940. In L. Mercier \& J. GierViskovatoff (Eds.), Mining women: Gender in the development of a global industry, 1670-2005. New York: Palgrave Macmillan.

Bordeau, L. \& Gavari-Barbas, M. (2016). World heritage, tourism and identity. Oxford: Routledge.

Brooks, A. (1997). Post-feminism: Feminism, cultural theory and cultural forms. New York: Routledge.

Bryman, A. (2002). Samhällsvetenskapliga metoder. (Transl. B. Nilsson). [Original title: Social research methods]. Egypt: Sahara Printing.

Calissendorff, K. (1988). Bergslagen - namnets medeltida bakgrund. I Boken om Bergslagen resa i en levande historia. Stockholm: Rubicon.

Coleman, R. (2014). Inventive feminist theory: Representation, materiality and intensive time. Journal Women: A Cultural Review, 25, 27-45. doi: 10.1080/09574042.2014.901098

Collins, P. (2012). Social inequality, power and politics: Intersectionality and American pragmatism in dialogue. Journal of Speculative Philosophy 26(2), 442-457. doi: 10.1353/jsp.2012.0037

Cook, J. \& Fonow, M. M. (1986). Knowledge and women's interests: Issues of epistemology and methodology in feminist sociological research. Sociological Inquiry, 56(1), 2-29. doi: 10.1111/j.1475-682X.1986.tboo073.x

Ćopić, S., Đorđević, J., Lukić, T., Stojanović, V., Đukičin, S., Besermenji, S., Stamenković, I. \& Tumarić, A. (2014). Transformation of industrial heritage. An example of tourism industry development in the Ruhr area (Germany). Geographica Pannonica 18(2), 43-50. doi: 10.5937/GeoPan1402043C

Daugstad, K. (2008). Negotiating landscape in rural tourism. Annals of Tourism Research, 35(2), 402426. doi: 10.1016/j.annals.2007.10.001

Edwards, J. \& Llurdes, J. (1996). Mines and quarries: Industrial heritage tourism. Annals of Tourism Research, 23(2), 341-363. doi: 10.1016/0160-7383(95)00067-4

Ekman, A-K. (1996). Inledning. In Ekman, Ann-Kristin (Ed.), Bortom bruksandan, Göteborg: SIR 43.

Fagersta Kommun (2018). Engelsbergs Bruk. Retrieved from http:/fagersta.se/turism/engelsbergsbruk.4.77ce246e14d7acob88249256.html

Halewood, C. \& Hannam, K. (2001). Viking heritage tourism: Authenticity and commodification. Annals of Tourism Research, 28(3), 565-580. doi: 10.1016/S0160-7383(00)00076-1

Hall, S. (1997). The work of representation. In S. Hall (Ed.), Representation: Cultural representations and signifying practices (pp.15-39). London: Sage.

Holsti, O. R. (1969). Content analysis for social sciences and humanities. Reading, Mass.: Addison-Wesley 
Hsieh, H.-F. \& Shannon, S. E. (2009). Three approaches to qualitative content analysis. Qualitative Health Research, 15(9), 1277-1288. doi: 10.1177/1049732305276687

Hultman, J. \& Hall, C.M. (2011). Tourism place-making: Governance of locality in Sweden. Annals of Tourism Research, 39(2), 547-570. doi: 10.1016/j.annals.2011.07.001

Intresseföreningen Bergslaget (n.d.). Bergslagssatsningen Kultur och turism. Retrieved from http://www.bergslaget.se/kultur-och-turism

Insch, G. S., Moore, J. E. \& Murphy, L. D. (1997). Content analysis in leadership research: Examples, procedures, and suggestions for future use. The Leadership Quarterly, 8(1), 1-25. doi: 10.1016/S1048-9843(97)90028-X

Jenkins, O. (2003). Photography and travel brochures: The circle of representation. Tourism Geographies, 5(3), 305-328. doi: 10.1080/14616680309715

Jakobsson, M. (2009). Från industrier till upplevelser. En studie av symbolisk och materiell omvandling i Bergslagen. Örebro University: Örebro Studies in Human Geography

Keskitalo, E. C. H. \& Schilar, H. (2017). Co-constructing "northern" tourism representations among tourism companies, DMOs and tourists. An example from Jukkasjärvi, Sweden. Scandinavian Journal of Hospitality and Tourism, 17(4), 406-422. doi: 10.1080/15022250.2016.1230517

Kolcun, M., Kot, S. \& Grabara, I. (2014). Use of elements of semiotic language in tourism marketing. International Letters of Social and Humanistic Sciences, 26, 1-6. doi: 10.18052/www.scipress.com/ILSHS.26.1

Kondracki, N. L. \& Wellman, N. S. (2002). Content analysis: Review of methods and their applications in nutrition education. Journal of Nutrition Education and Behavior, 34(4), 224-230. doi: 10.1016/s1499-4046(06)60097-3

Lakoff, R. \& Bucholtz, M. (2004). Language and woman's place: Texts and commentaries. Oxford: Oxford University Press.

Lew, A. (2017). Tourism planning and place making: Place-making or placemaking? Tourism Geographies, 19(3), 448-466. doi: 10.1080/14616688.2017.1282007

Luchini, P. L. (2010). The construction of social reality through the use of the English language: A study with Argentinean pre-service teachers. HOW, 17(1), 91-107.

Lykke, N. (2010). Feminist studies: A guide to intersectional theory, methodology and writing. New York: Routledge.

Länsstyrelsen Gävleborg (2018). Axmar bruk. Retrieved from https://www.lansstyrelsen.se/gavleborg/besoksmal/kulturreservat/axmar-bruk.html

Länsstyrelsen Värmland (2018). Långban. Retrieved from http://www.lansstyrelsen.se/Varmland/Sv/samhallsplanering-ochkulturmiljo/landskapsvard/se-och-besoka/langban/Pages/index.aspx

Länsstyrelsen Västmanland (2018). Värdsarvet Engelsberg bruk. Retrieved from http://www.lansstyrelsen.se/Vastmanland/Sv/samhallsplanering-och-kulturmiljo/skyddadbebyggelse/Pages/index.aspx

Martin, P. \& Papadelos, P. (2017). Who stands for the norm? The place of metonymy in androcentric language. Social Semiotics, 27(1), 39-58. doi: 10.1080/10350330.2016.1145371

Miles, M.B. \& Huberman, A.M. (1994). Qualitative data analysis: An expanded sourcebook. Beverly Hills: Sage.

Ohlander, A-S \& Strömberg, U-B (1996). Tusen svenska kvinnoår. Svensk kvinnohistoria från vikingatid till nutid. Rabén Prisma. 
Ollivier, M. \& Tremblay, M. (2000). Questionnements feministes et methodologie de la recherche. Montreal et Paris: L'Harmattan.

Pashkevich, A. (2017). Processes of reinterpretation of mining heritage: The case of Bergslagen, Sweden. Almatourism, 8(7), 107-123.

Patton, M. Q. (2005). Qualitative research. California: Thousand Oaks.

Pritchard, A. \& Morgan, N. J. (2000). Privileging the male gaze: Gendered tourism landscapes. Annals of Tourism Research, 27(4), 884-905. doi: 10.1016/S0160-7383(99)00113-9

Ren, C. \& Blichfeldt, B. S (2011). One clear image? Challenging simplicity in place branding. Scandinavian Journal of Hospitality and Tourism, 11(4), 416-434. doi: 10.1080/15022250.2011.598753

Robert, N. (2014). Getting intersectional in museums. Museums \& Social Issues, 9(1), 24-33. doi: 10.1179/1559689314Z.00000000017

Sims, R. (2009). Food, place and authenticity: Local food and the sustainable tourism experience. Journal of Sustainable Tourism, 17(3), 321-336. doi: 10.1080/09669580802359293

Tallichet, S. E. (2000). Barriers to women's advancement in underground coal mining. Rural Sociology, 65(2), 234-252. doi: 10.1111/j.1549-0831.2000.tboo027.x

UNESCO, (2018). Engelsbergs Ironworks. Retrieved from https://whc.unesco.org/en/list/556

Veal, A.J. (2011). Research methods for leisure and tourism: A practical guide. England: Pearson Education.

Värmlands Museum. (2018). Startsida. Retrieved from https://varmlandsmuseum.se/langban/

Waterton, E. \& Watson, S. (2014). The semiotics of heritage tourism. Bristol, UK: Channel View Publications.

Whorf, B. (1956). The relation of habitual thought and behavior to language. Cambridge, MA: MIT Press.

Xie, P. F. (2006). Developing industrial heritage tourism: A case study of the proposed jeep museum in Toledo. Tourism Management, 27(6), 1321-1330. doi: 10.1016/j.tourman.2005.06.010

Xie, P. F. (2015a). A life cycle model of industrial heritage development. Annals of Tourism Research, 55, 141-154.

Xie, P.F. (2015b). Industrial heritage tourism. Bristol, UK: Channel View Publications.

MINÉA FUNK has a Masters degree in Tourism Studies from Dalarna University, Sweden. The combination of working in cultural heritage tourism and further tourism studies has developed her interest in research of Industrial heritage tourism and in particular the development of mining heritage sites in central Sweden. Institutional address: School of Technology and Business Studies, Högskolan Dalarna, Turismvetenskap, 79188 Falun, Sweden.

ALBINA PASHKEVICH is an Associate Professor in Tourism Studies at the Centre for Tourism and Leisure Research (CeTLeR), Dalarna University, Sweden. Her research interests include a wide range of topics primarily connected to Arctic tourism development - representations of indigenous culture, tourism management, power relations and institutional structures impact on tourism development. She also works with issues connected to the sustainable use of mining heritage in the area of Bergslagen, Sweden and remote Arctic mining communities. Institutional address: School of Technology and Business Studies, Högskolan Dalarna, Turismvetenskap, 79188 Falun, Sweden.

Submitted on January 22, 2020

Accepted on March 31, 2020 